\title{
Comparison of extensometric results measured in the Vyhne Tidal Station (Slovakia) and in the Sopronbánfalva Geodynamic Observatory (Hungary)
}

\author{
Gyula MENTES ${ }^{1, *}\left(\mathbb{D}\right.$, Ladislav BRIMICH${ }^{2}$ (D), Martin BEDNÁRIK ${ }^{2}$ (D), \\ Jozef BÓDI ${ }^{2}$ (D) \\ ${ }^{1}$ Institute of Earth Physics and Space Science (ELKH EPSS), \\ Csatkai E. u. 6-8, 9400 Sopron, Hungary \\ ${ }^{2}$ Earth Science Institute of the Slovak Academy of Sciences, \\ Dúbravská cesta 9, P.O. BOX 106, 84005 Bratislava, Slovak Republic
}

\begin{abstract}
Two extensometer stations have been set up at the margin of the Pannonian Basin to monitor tectonic movements as well as Earth tides and related phenomena. Because the Sopronbánfalva Geodynamic Observatory (SGO) in Hungary and the Vyhne Tidal Station (VTS) in Slovakia are located in different geological, topographic, and tectonic environments, the analysis and comparison of the extensometer data measured here provides a useful opportunity to interpret the observed data. The tectonic deformation at the SGO shows an average contraction of: $-2.94 \mu$ str y $^{-1}\left(1 \mu\right.$ str is $10^{-6}$ relative deformation) which can be explained by the uplift of the Alps and the anticlockwise motion of the Adria microplate, causing compression in the Eastern Alps. At the VTS an average compression of -14.8 nstr $^{-1}$ ( 1 nstr is $10^{-9}$ relative deformation) was measured which can be explained by the NW compression direction in this area. The measured deformations in both observatories show a good agreement with the results of GPS measurements. The deformation at the VTS is characterized by small dilatation anomalies caused by the different topographic, tectonic environment and probably by the high heat flow in the area of the station. At this station the calculated amplitude factors for O1, P1, K1, M2 are $1.01482,1.21691,0.83173,1.09392$ and the ocean load corrected values are 1.10817, $1.35717,0.92809,1.28812$, respectively. At the SGO the calculated amplitude factors for the same tidal components are 0.58776, 0.38967, 0.41548, 1.00564 and the ocean load corrected values are $0.98893,1.89117,1.00430,1.04962$, respectively. These results show that the effect of the ocean tide loading is greater at Sopronbánfalva, than at Vyhne. Based on the comparison, we can say that the result of the local strain measurement can be considered realistic.
\end{abstract}

Key words: extensometer, Earth tides, tectonic deformation, ocean tide loading, comparison of observatories

\footnotetext{
*corresponding author, e-mail: mentes.gyula@epss.hu, phone: +36-99-508379
} 


\section{Introduction}

In 1984, a quartz-tube extensometer was built in Vyhne and in 1990 in Sopronbánfalva. Both extensometers with photorecorder were installed in scientific cooperation between the former Institute of Physics of the Earth of the then USSR Academy of Sciences, Moscow and the Geophysical Institute of the Slovak Academy of Sciences (Brimich, 1988; Brimich and Latynina, 1989) and the former Geodetic and Geophysical Institute of the Hungarian Academy of Sciences (Mentes, 1991). The photorecorder of the Hungarian extensometer was replaced with the Hungarian capacitive transducer in 1991, and the Slovak one in 2001 for electronic data recording. Since the measuring instruments are of the same type (Mentes, 2010) and capable to monitor deformations and Earth tides, it is a good opportunity to compare the results measured at the two geodynamic observatories which lie in different geologic, topographic and tectonic environments. In this paper the long-term tectonic deformations, tidal parameters are compared and possible explanations are discussed.

\section{Observation sites}

Figure 1 shows the location of the SGO and the VTS. The coordinates of the observatories and the parameters of the instruments are given in Table 1. The SGO is located in the Sopron Mountains, which belong to the extensions of the Eastern Alps. The geological structure of the observatory and its surroundings is described in detail by Haas (2001) and Eper-Pápai et al. (2014). The yearly mean value of the temperature is $10.4^{\circ} \mathrm{C}$ in the gallery and the yearly and daily temperature variations are less than $0.5^{\circ} \mathrm{C}$ and $0.05^{\circ} \mathrm{C}$, respectively. The relative humidity is $90 \%$ and it is nearly constant.

The VTS is located in Central Slovakia in the centre of the Štiavnické vrchy Mts. range in the cadastre of the village of Vyhne $(10 \mathrm{~km}$ from Banská Štiavnica). The observatory is located in the horizontal gallery of the former mining gallery of St. Anthony of Padua. The gallery was mostly driven in Variscan-age granites. At a distance of $43 \mathrm{~m}$ from the gallery entrance there is a distinct penetration of young dacite, striking $\mathrm{N}-\mathrm{S}$ into ancient granites. The recording chamber is located beyond this penetration in comparatively 
well preserved granite. A vein zone with mylonite and quartz lenses runs along the gallery. Less strong places have been reinforced by a protective wall. The extensometric station was built in the most solid part of granite. The overlay of the gallery is about $50 \mathrm{~m}$ thick. The yearly average temperature in the gallery is nearly constant: $8.25 \pm 0.16{ }^{\circ} \mathrm{C}$. The observatory and the geological settings of its surroundings are described in detail by Brimich et al. (2016).

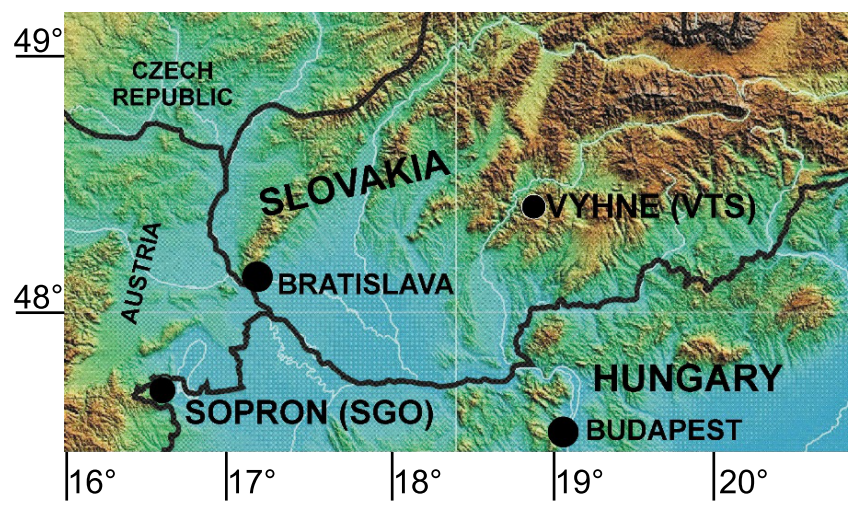

Fig. 1. Location of the observatories.

Table 1. Location and parameters of the extensometers.

\begin{tabular}{lcccccc}
\hline Station & \multicolumn{2}{c}{$\begin{array}{c}\text { Coordinates of } \\
\text { the observatories }\end{array}$} & \multicolumn{3}{c}{$\begin{array}{c}\text { Parameters of } \\
\text { the extensometers }\end{array}$} \\
& Longitude & Latitude & $\begin{array}{c}\text { Height a.s.l. } \\
{[\mathrm{m}]}\end{array}$ & Azimuth & $\begin{array}{c}\text { Length } \\
{[\mathrm{m}]}\end{array}$ & $\begin{array}{c}\text { Scale factor } \\
{[\mathrm{nstr} / \mathrm{mV}]}\end{array}$ \\
\hline VTS & $48^{\circ} 29^{\prime} 52^{\prime \prime}$ & $18^{\circ} 49^{\prime} 48^{\prime \prime}$ & 420 & $55^{\circ}$ & 20.5 & -0.1141 \\
SGO & $47^{\circ} 40^{\prime} 55^{\prime \prime}$ & $16^{\circ} 33^{\prime} 32^{\prime \prime}$ & 280 & $116^{\circ}$ & 22 & -0.0955 \\
\hline
\end{tabular}

\section{Method}

At SGO extensometric, temperature and barometric pressure data were recorded with one minute sampling rate. At VTS the extensometric and temperature data were recorded. The sampling rate was 10 minutes. In both observatories inner and outher temperatures were measured. Highfrequency signals such as earthquakes, microseismic noises were filtered out 
by an analog filter built into the capacitive sensor. The data preprocessing was carried out by the Tsoft program (Van Camp and Vauterin, 2005). Steps and spikes were corrected first and then the data were calibrated. After that gaps in the extensometric data series were filled with adjusted theoretical values. The calibrated and corrected data (extensometric, temperature, barometric) were decimated to 1 sample/hour for the tidal analysis with the ETERNA 3.40 Earth tide data processing package (Wenzel, 1996), using the Wahr-Dehant Earth model (Wahr, 1981; Dehant, 1987) and the HW95 tidal potential catalogue (Hartmann and Wenzel, 1995). A built-in high-pass filter of the programme package (with a cut-off frequency of $0.8 \mathrm{cpd}$ ) was used during the tidal evaluation. Tidal analysis was carried out decomposing the data into one year segments. The correction of extensometric data for temperature and barometric pressure was made by the ETERNA 3.40. Since the barometric pressure was not measured at the VTS, the extensometric data were only corrected here for the temperature. For comparison of measured tidal parameters data of both observatories from 2015 to 2019 were used. The effect of ocean tide loading on the O1, $\mathrm{P} 1, \mathrm{~K} 1, \mathrm{M} 2$ tidal constituent was also compared.

For observation of the long-term tectonic deformation the calibrated and uncorrected strain data were used. Long-term tectonic deformations were observed from 2001 to 2019 at both observatories. To determine the average yearly rate of the tectonic movements, a linear regression line was fitted to the measured extensometric data.

\section{Results and discussion}

Tables 2 and 3 show the results of the measured amplitude factors at the VTS and SGO, respectively. The amplitude factors obtained at the VTS are close to 1 , the ones for the diurnal waves are smaller than 1 at SGO.

At both observatories ocean tide loading effect was calculated using the same 13 ocean tide loading models with different Earth models and Green functions (Mentes, 2021). The test of models was carried out in the case of the diurnal and semi-diurnal tidal harmonic constituents O1, P1, K1 and M2. At both observatories only a negligible difference between the individual global ocean tide loading models, mainly due to using different Earth models and Green functions, was found. Table 4 shows the average 
Table 2. Amplitude factors measured at the VTS in years 2015-2019. (S.D. denotes standard deviation).

\begin{tabular}{|c|c|c|c|c|c|c|c|}
\hline \multirow{2}{*}{$\begin{array}{l}\text { Tidal } \\
\text { wave }\end{array}$} & \multicolumn{2}{|c|}{ Frequency [cpd] } & \multicolumn{5}{|c|}{ Amplitude factors } \\
\hline & from & to & 2015 & $2016-17$ & 2018 & 2019 & Average \pm S.D. \\
\hline O1 & 0.91139 & 0.94799 & 0.92290 & 1.01848 & 0.95806 & 1.15984 & $1.01482 \pm 0.09044$ \\
\hline M1 & 0.94799 & 0.98185 & 249 & 1.24665 & 0.92656 & 1.27759 & $1.21082 \pm 0.17288$ \\
\hline $\mathrm{P} 1$ & 0.98185 & 0.99863 & 1.18612 & 1.22616 & 1.12991 & 1.32544 & $1.21691 \pm 0.07138$ \\
\hline K1 & 0.99863 & 1.02362 & 0.84720 & 0.84229 & 0.80756 & 0.82985 & $0.83173 \pm 0.01532$ \\
\hline J1 & 1.02362 & 1.0 & 1.93703 & 0.84021 & 1.32036 & 0.63418 & $1.18295 \pm 0.50153$ \\
\hline OO1 & 1.05748 & 1.47024 & 0.80896 & 2.00610 & 0.87849 & 1.10349 & $1.19926 \pm 0.47838$ \\
\hline $2 \mathrm{~N} 2$ & 1.47024 & 1.88026 & 1.11215 & 1.07458 & 0.49208 & 1.24118 & $0.98000 \pm 0.28840$ \\
\hline $\mathrm{N} 2$ & 1.88026 & 1.91412 & 1.12260 & 1.22752 & 1.07856 & 0.98466 & $1.10334 \pm 0.08731$ \\
\hline M2 & 1.91412 & 1.95041 & 0.99549 & 1.13071 & 1.05349 & 1.19597 & $1.09392 \pm 0.07598$ \\
\hline $\mathrm{L} 2$ & 1.95042 & 1.98428 & 1.44919 & 1.12497 & 1.50196 & 2.82382 & $1.72499 \pm 0.65063$ \\
\hline $\mathrm{S} 2$ & 1.98428 & 2.00273 & 0.84675 & 1.07515 & 1.20268 & 1.29096 & $1.10389 \pm 0.16711$ \\
\hline $\mathrm{K} 2$ & 2.00273 & 2.45194 & 0.90737 & 1.03145 & 1.12507 & 1.10809 & $1.04300 \pm 0.08588$ \\
\hline
\end{tabular}

Table 3. Amplitude factors measured at the SGO in years 2015-2019. (S.D. denotes standard deviation).

\begin{tabular}{cccccccc}
\hline \multirow{2}{*}{$\begin{array}{c}\text { Tidal } \\
\text { wave }\end{array}$} & \multicolumn{2}{c}{ Frequency [cpd] } & \multicolumn{5}{c}{ Amplitude factors } \\
& from & to & 2015 & 2016 & 2017 & $2018-19$ & Average \pm S.D. \\
\hline O1 & 0.91139 & 0.94799 & 0.70158 & 0.55512 & 0.53233 & 0.56166 & $0.58767 \pm 0.06666$ \\
M1 & 0.94799 & 0.98185 & 0.59709 & 0.81905 & 0.95501 & 0.72542 & $0.77414 \pm 0.13082$ \\
P1 & 0.98185 & 0.99863 & 0.50088 & 0.24847 & 0.45377 & 0.35555 & $0.38967 \pm 0.09693$ \\
K1 & 0.99863 & 1.02362 & 0.49347 & 0.31561 & 0.52826 & 0.32456 & $0.41548 \pm 0.09623$ \\
J1 & 1.02362 & 1.05748 & 0.50317 & 1.13679 & 1.03896 & 0.48123 & $0.79004 \pm 0.29994$ \\
OO1 & 1.05748 & 1.47024 & 0.43591 & 1.65943 & 1.26234 & 0.76194 & $1.02991 \pm 0.46770$ \\
2N2 & 1.47024 & 1.88026 & 0.82349 & 0.6578 & 0.73234 & 1.64469 & $0.96458 \pm 0.39702$ \\
N2 & 1.88026 & 1.91412 & 0.92184 & 1.00549 & 1.01198 & 1.34950 & $1.07220 \pm 0.16400$ \\
M2 & 1.91412 & 1.95041 & 1.00816 & 1.00821 & 1.00358 & 1.00261 & $1.00564 \pm 0.00257$ \\
L2 & 1.95042 & 1.98428 & 1.62786 & 1.13612 & 1.01258 & 1.46370 & $1.31007 \pm 0.24665$ \\
S2 & 1.98428 & 2.00273 & 1.06800 & 1.80362 & 0.64401 & 1.60345 & $1.27977 \pm 0.45503$ \\
K2 & 2.00273 & 2.45194 & 1.04912 & 0.92522 & 0.60884 & 0.36038 & $0.73589 \pm 0.26977$ \\
\hline
\end{tabular}


uncorrected amplitude factors obtained from yearly measurements between 2015 and 2019 and the average corrected amplitude factors for ocean tide loading of the O1, P1, K1, M2 tidal constituents obtained at the VTS and SGO. The corrected amplitude factors are the average of amplitude factors calculated from ten SPOTL: EOT11a, HAMTIDE11a, OSU.TPXO72atlas, OSU.TPXO72, TPX070, DTU10, CSR4.0, FES2004, FES95.2.1, SCHW1 (Agnew, 2013) and three FOTLP: FES2012, FES2014b, GOT00.2 (created by Scherneck and Bos (http://holt.oso.chalmers.se/loading/)) ocean tide loading models according to Mentes (2021) and Brimich et al. (2021).

Table 4. Comparison of the effectiveness of ocean tide loading correction at the VTS and SGO in the case of O1, P1, K1 and M2 tidal waves on the basis of extensometric measurements between 2015-2019. (S.D. denotes standard deviation).

\begin{tabular}{cccccc}
\hline \multirow{2}{*}{ Observatory } & \multirow{2}{*}{ Tidal waves } & \multicolumn{4}{c}{ Average amplitude factors } \\
& & Uncorrected & \pm S.D. & Corrected & \pm S.D. \\
\hline \multirow{2}{*}{ VTS } & O1 & 1.01482 & 0.10443 & 1.10817 & 0.02831 \\
& P1 & 1.21691 & 0.08242 & 1.35717 & 0.07076 \\
& K1 & 0.83173 & 0.01769 & 0.92809 & 0.06272 \\
SGO & M2 & 1.09392 & 0.08773 & 1.28812 & 0.01787 \\
& O1 & 0.58767 & 0.07697 & 0.98893 & 0.05520 \\
& P1 & 0.38967 & 0.11192 & 1.89117 & 0.02841 \\
& K1 & 0.41548 & 0.11112 & 1.00430 & 0.03712 \\
& M2 & 1.00564 & 0.00297 & 1.04962 & 0.01941 \\
\hline
\end{tabular}

At the VTS the corrected amplitude factor became better only for K1 and the others became slightly larger than the uncorrected. At the SGO, the small amplitude factors of the diurnal waves, with the exception of the $\mathrm{P} 1$ wave, became close to 1 due to the correction. We have not yet found a reliable explanation for the poor value obtained for the P1 wave, it may be related to the cavity effect of the observatory, as the wall of the observatory perpendicular to the extensometer is exposed to strong sunlight. Further research is needed to clarify the real reason for this. Residues remaining after the correction suggest that local effects (e.g. topographic, cavity) affect the measurement sites, which requires also further investigation. A detailed study of ocean tidal loading effect at the SGO is described by Mentes (2021), while at VTS by Brimich et al. (2021). 
Figures 2 and 3 show the results of the long-term observation of tectonic deformation at the VTS and at the SGO, respectively. Comparing the tectonic deformations, it can be seen that the deformation in Vyhne has a large variability, while at the SGO, there is a continuous compression

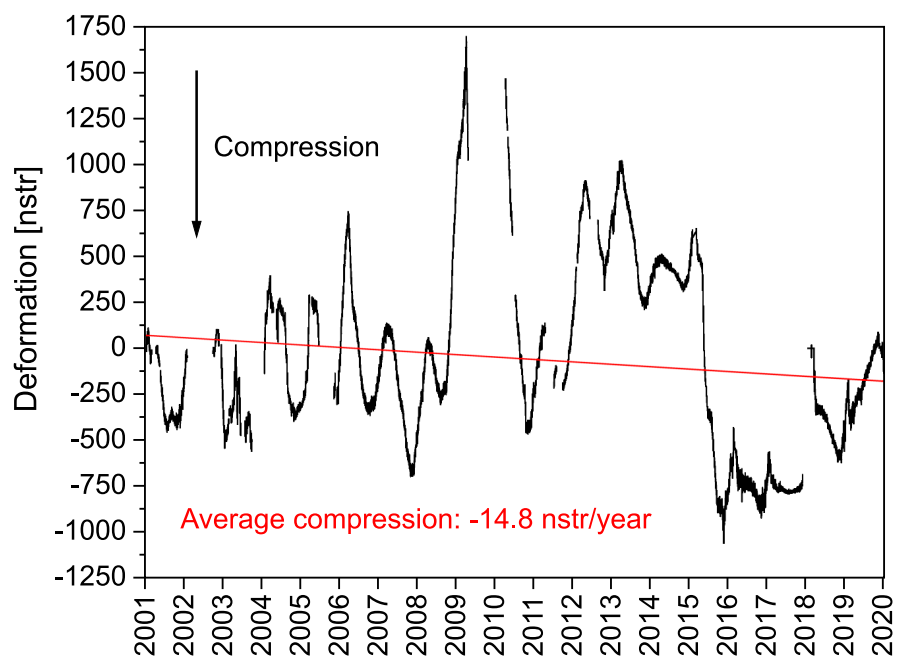

Fig. 2. Tectonic deformation measured at the VTS between 2001 and 2019.

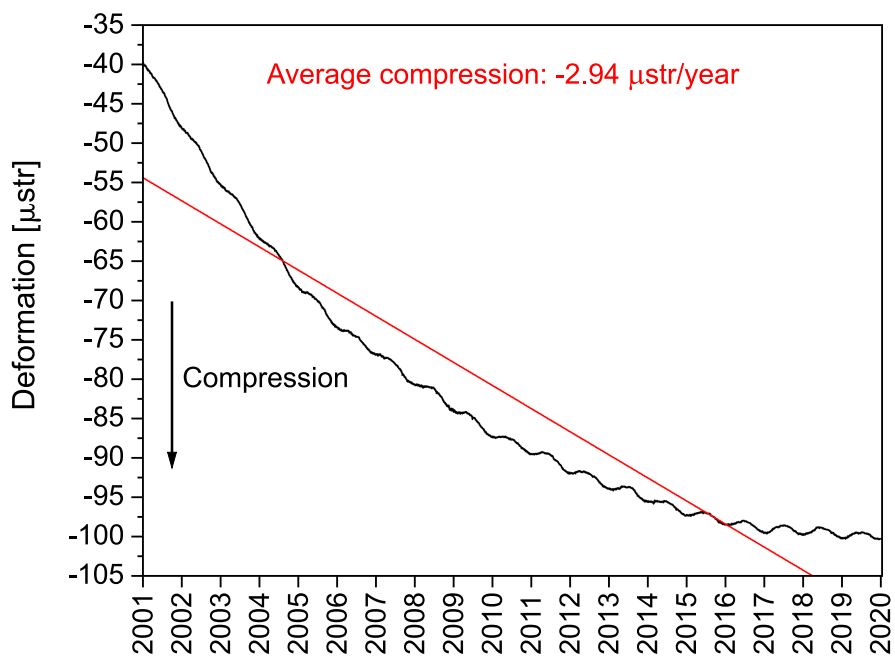

Fig. 3. Tectonic deformation measured at the SGO between 2001 and 2019. 
with a changing rate. This is probably because while there are no faults in the immediate vicinity of the SGO, while there are several smaller ones near the VTS (Brimich et al., 2016). This local strain rate measured by the extensometer was compared by the strain rates determined by permanent and epoch-wise GPS measurements (CEPER, CEGERN, SGRN, TATRY, EMO) in Slovakia. Although local deformation measurements are difficult to compare with long-baseline GPS measurements, the latter still provide some possibility of verifications of the local measurements. According to Hefty et al. (2010) the measured GPS velocities are oriented randomly with magnitude up to $3 \mathrm{mmy}^{-1}$. In the surroundings of Vyhne the strain rates measured by GPS are small and the temporal strain rate changes in the different directions can cause large deformation variation in the local strain measured in Vyhne. The GPS measurements show compression and extension areas in central Slovakia. At VTS, an average extensional strain rate

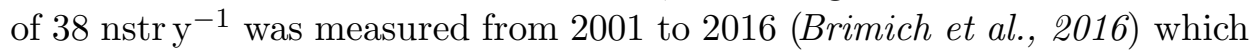
has changed to a compressional of -14.8 nstr $^{-1}$ till now. Based on the comparison, we can say that the result of the local strain measurement can be considered realistic.

The 19-year long strain measurements at the SGO show a compressive strain with varying rate at the foot of the Eastern Alps. The average strain rate is $-6.4 \mu \mathrm{str}^{-1}$ ( $1 \mu \mathrm{str}$ is $10^{-6}$ relative deformation). The measured compressive strain is in good accordance with the GPS and geophysical strain measurements in this region. The strain rates determined from GPS measurements in the Hungarian GPS Geodynamic Reference Network and the Central European GPS Reference Network are three orders of magnitude smaller than the values measured by the extensometer at the SGO (Grenerczy et al., 2000, 2005). It can be explained by the difference of the measurement techniques. While the extensometer measures local strain rates, only regional strain rates for large areas can be determined from GPS measurements. The decreasing strain rate should be the result of the complex tectonic processes in this region. We can assume that the uplift of the Alps, tectonic processes in the East Alpine region, folding in the Pannonian Basin (Bada et al., 2007; Bus et al., 2009) and earthquakes play the most important role in the varying strain rate. A possible explanation for the annual strain rate variation was given by Mentes and Kiszely (2019). They examined in detail the effect of earthquakes occurred within $200 \mathrm{~km}$ 
from the observatory in two sectors around the azimuth of the extensometer $\left(116^{\circ}\right): 116^{\circ} \pm 15^{\circ}$ and $296^{\circ} \pm 15^{\circ}$. They found that earthquakes to the west of SGO generally increase the compressive strain rate, while earthquakes in the Pannonian Basin, with some exceptions, have no significant effect on the local strain rate variations measured at the SGO. The reason for the former is probably the tectonic processes in the vicinity of the Mur-Mürz fault line (Bada et al., 2007; Olaiz et al., 2009; Brückl et al., 2010; Salcher et al., 2012; Bokelmann et al., 2013), while for the latter is the folding in the Pannonian Basin which absorbs the energy of earthquakes (Cloetingh et al., 1999; Caporali et al., 2009; Dombrádi et al., 2010).

\section{Conclusions}

The uniform construction of the extensometers at SGO and VTS ensures that in the course of comparison any differences in the measurement characteristics can be attributed to geological and topographical properties.

Tidal analysis of the extensometric data between 2015 and 2019 revealed that the measured amplitude factors are close to the theoretical values at the VTS, while they are 44-60\% smaller in the diurnal band at the SGO.

The correction of strain data for ocean tide loading slightly increased the amplitude factors of the diurnal and semidiurnal waves measured at the VTS, while at the SGO the measured small amplitude factors of the diurnal waves were corrected, with the exception of P1, close to 1 and the same for the semidiurnal M2 wave was only slightly increased. These results show that the effect of the ocean tide loading is greater at Sopronbánfalva, than at Vyhne. One possible explanation for this is that the VTS is somewhat further away from the oceans than the SGO. Another possible reason can be that the small faults in the surroundings of the VTS can reduce the effect of the ocean loadings. The reason for the small uncorrected amplitude factors of the diurnal waves at the SGO which became close to 1 due to ocean tide loading correction needs further investigations.

Based on long-term tectonic motion observation, it can be said that the curve recorded at Vyhne is much more disturbed than at SGO, but the rate of tectonic deformation in Vyhne is three orders of magnitude lower than in SGO. This may be due to different geographical, geological and tectonic conditions. Nevertheless, at both observatories, the measured strain rate 
show a good agreement with the data from GPS measurements. All this proves that both observatories are suitable for reliable observation of local deformations and beside GPS measurements local tectonic observations can contribute to better understanding of tectonic processes.

Acknowledgements. The research was funded by the VEGA grant agency under project No. 2/0013/21, as well as by the Hungarian National Research Fund (OTKA) under project K 109060 .

\section{References}

Agnew D. C., 2013: SPOTL: Some Programs for Ocean-Tide Loading. Institute of Geophysics and Planetary Physics, Scripps Institution for Oceanography, University of California. Technical Report, August 31, 2013.

Bada G., Horváth F., Dövényi P., Szafián P., Windhoffer G., Clothing S., 2007: Presentday stress field and tectonic inversion in the Pannonian basin. Glob. Planet. Change, 58, 1-4, 165-180, doi: 10.1016/j.gloplacha.2007.01.007.

Bokelmann G., Qorbani E., Bianchi I., 2013: Seismic anisotropy and large-scale deformation of the Eastern Alps. Earth Planet. Sci. Lett., 383, 1-6, doi: 10.1016/j.epsl. 2013.09.019.

Brimich L., 1988: Extensometric measurements at the Vyhne tidal station. Contr. Geophys. Inst. Slov. Acad. Sci., 18, 58-62.

Brimich L., Latynina L. A., 1989: The results of the extensometric observations in Vyhne. Proceedings of the $6^{\text {th }}$ International Symposium "Geodesy and Physics of the Earth", ZIPE, Potsdam, 239-254.

Brimich L., Bednárik M., Bezák V., Kohút I., Bán D., Eper-Pápai I., Mentes G., 2016: Extensometric observation of Earth tides and local tectonic processes at the Vyhne station, Slovakia. Contrib. Geophys. Geod., 46, 2, 75-90, doi : 10.1515/congeo-201 6-0006.

Brimich L., Bednárik M., Bódi J., Mentes G., 2021: Test of ocean tide loading models on the basis of strain data measured in the Vyhne Tidal Station, Slovakia. Presentation on the $19^{\text {th }}$ International Symposium on Geodynamics and Earth Tides. June 22-26, 2021, Wuhan, China.

Brückl E., Behm M., Decker K., Grad M., Guterch A., Keller G. R., Thybo H., 2010: Crustal structure and active tectonics in the Eastern Alps. Tectonics, 29, 2, TC2011, doi: 10.1029/2009TC002491.

Bus Z., Grenerczy Gy., Tóth L., Mónus P., 2009: Active crustal deformation in two seismogenic zones of the Pannonian region - GPS versus seismological observations. Tectonophysics, 474, 1-2, 343-352, doi: 10.1016/j.tecto.2009.02.045.

Caporali A., Aichhorn C., Barlik M., Becker M., Fejes I., Gerhatova L., Ghitau L., Grenerczy Gy., Hefty J., Krauss S., Medak D., Milev G., Mojzes M., Mulic M., Nardo A., Pesec P., Rus T., Simek J., Sledzinski J., Solaric M., Stangl G., Stopar B., 
Vespe F., Virág G., 2009: Surface kinematics in the Alpine-Carpathian-Dinaric and Balkan region inferred from a new multi-network GPS combination solution. Tectonophysics, 474, 1-2, 295-321, doi: 10.1016/j.tecto.2009.04.035.

Cloetingh S., Burov E., Poliakov A., 1999: Lithosphere folding: Primary response to compression? (from central Asia to Paris basin). Tectonics, 18, 6, 1064-1083, doi: 1029/1999TC900040.

Dehant V., 1987: Tidal parameters for an inelastic Earth. Phys. Earth Planet. Inter., 49, 1-2, 97-116, doi : 10.1016/0031-9201(87)90134-8.

Dombrádi E., Sokoutis D., Bada G., Cloetingh S., Horváth F., 2010: Modelling recent deformation of the Pannonian lithosphere: Lithospheric folding and tectonic topography. Tectonophysics, 484, 1-4, 103-118, doi: 10.1016/j.tecto.2009.09.014.

Eper-Pápai I., Mentes Gy., Kis M., Koppán A., 2014: Comparison of two extensometric stations in Hungary. J. Geodyn., 80, 3-11, doi: 10.1016/j.jog.2014.02.007.

Grenerczy Gy., Kenyeres A., Fejes I., 2000: Present crustal movement and strain distribution in Central Europe inferred from GPS measurements. J. Geophys. Res., 105, B9, 21835-21846, doi: 10.1029/2000JB900127.

Grenerczy Gy., Sella G., Stein S., Kenyeres A., 2005: Tectonic implications of the GPS velocity field in the northern Adriatic region. Geophys. Res. Lett., 32, 16, L16311, doi: $10.1029 / 2005$ GL022947.

Haas J. (Ed.), 2001: Geology of Hungary. Budapest, Eötvös University Press, 317 p.

Hartmann T., Wenzel H.-G., 1995: The HW95 tidal potential catalogue. Geophys. Res. Lett., 22, 24, 3553-3556, doi: 10.1029/95GL03324.

Hefty J., Hipmanová L., Gerhátová L., Igondová M., Droščák B., 2010: Recent geokinematics of Slovakia based on homogenized solutions of permanent and epoch GPS networks. Acta Geodyn. et Geomater., 7, 3, 159, 303-315.

Mentes Gy., 1991: Installation of a quartz tube extensometer at the Sopron Observatory. Bull. Inf. Marées Terrestres, 110, 7936-7939.

Mentes Gy., 2010: Quartz tube extensometer for observation of Earth tides and local tectonic deformations at the Sopronbánfalva Geodynamic Observatory, Hungary. Rev. Sci. Instrum., 81, 7, 074501, doi: 10.1063/1.3470100.

Mentes Gy., Kiszely M., 2019: Local tectonic deformations measured by extensometer at the eastern foothills of the Alps at the Sopronbánfalva Geodynamic Observatory, Hungary. Contrib. Geophys. Geod., 49, 3, 373-390, doi: 10.2478/congeo-20190019.

Mentes Gy., 2021: Comparison of Ocean Tide Loading Models Using Strain Data Measured in the Sopronbánfalva Geodynamic Observatory, Hungary. Int. J. Earth Sci. Geophys., 7, 1, 1-13, doi: 10.35840/2631-5033/1844.

Olaiz A. J., Muñoz-Martín A., De Vicente G., Vegas R., Cloetingh S., 2009: European continuous active tectonic strain-stress map. Tectonophysics, 474, 1-2, 33-40, doi: $10.1016 / j$. tecto. 2008.06 .023 .

Salcher B. C., Meurers B., Smit J., Decker K., Hölzel M., Wagreich M., 2012: Strikeslip tectonics and Quaternary basin formation along the Vienna Basin fault system inferred from Bouguer gravity derivatives. Tectonics, 31, 3, TC3004, doi : 10.1029/ $2011 \mathrm{TC} 002979$. 
Van Camp M., Vauterin P., 2005: Tsoft: graphical and interactive software for the analysis of time series and Earth tides. Comput. Geosci., 31, 5, 631-640, doi: 10.1016/j.ca geo.2004.11.015.

Wahr J. M., 1981: Body tides on an elliptical, rotating, elastic and oceanless Earth. Geophys. J. Int., 64, 3, 677-703, doi: 10.1111/j.1365-246X.1981.tb02690.x.

Wenzel H.-G., 1996: The nanogal software: Earth tide data processing package ETERNA 3.30. Bull. Inf. Marées Terrestres, 124, 9425-9439. 